\title{
Synthesis and comparing the antibacterial activities of pyrimidine derivatives
}

\author{
B ANDREWS ${ }^{\mathrm{a}, \mathrm{b}, \mathrm{c}, *}, \mathrm{~K}_{\mathrm{KOMATHI}}^{\mathrm{c}, \mathrm{d}}$ and S MOHAN ${ }^{\mathrm{c}, \mathrm{d}}$ \\ ${ }^{a}$ PG and Research Department of Chemistry, Islamiah College, Vaniyambadi 635 752, India \\ ${ }^{\mathrm{b}}$ Thiruvalluvar University, Vellore, Tamil Nadu, India \\ ${ }^{c}$ Priyadarshini Engineering College, Vaniyambadi, Tamil Nadu, India \\ ${ }^{\mathrm{d}}$ Anna University, Chennai, Tamil Nadu, India \\ Email: bandrews2006@yahoo.com
}

MS received 29 July 2016; revised 23 September 2016; accepted 29 December 2016

\begin{abstract}
A series of 10 derivatives of 5-(5-amino-1,3,4-thiadiazole-2-yl)-3,4-dihydro-6-methyl-4-phenylpyrimidin-2(1H)-one and 10 derivatives of 3,4-dihydro-5-(5-mercapto-4H-1,2,4-triazol-3-yl)-6-methyl-4phenyl pyrimidin-2 $(1 H)$-one have been synthesized. Among the synthesized derivatives, triazole substituted compounds have shown higher antibacterial inhibition when compared to the thiadiazole derivatives. All the structures of the newly synthesized compounds have been characterized by IR, ${ }^{1} \mathrm{H}$ and ${ }^{13} \mathrm{C}$ NMR, GC-MS and $\mathrm{CHN}$ analysis. Most of the compounds have shown promising antibacterial activity when compared with the standard drug ciprofloxacin.
\end{abstract}

Keywords. 5-amino thiadiazole; 5-amino triazole; hydrazine carbothioamide; pseudomonas aeruginosa; staphylococcus aureus; escherichia coli.

\section{Introduction}

The pyrimidine and its derivatives have a wide variety of applications in different fields, prominently for biological treatment process, ${ }^{1-8}$ such as antitumor, anticancer, anti-inflammatory, anti-hypertensive, antibacterial and antifungal agents, etc. The five-membered heterocyclic ring substituted in pyrimidine derivatives have moderate inhibition against the bacterial species. ${ }^{9}$ In order to improve the antibacterial activity, we have synthesized twenty pyrimidine derivatives.

The pyrimidine and its derivatives have been synthesized by using various methods. In continuation of this work, novel pyrimidine derivatives were synthesized by using the reported procedure for the first step. ${ }^{10,11}$ These pyrimidine derivatives have a large number of reactive sites to produce the substituted derivatives. ${ }^{12-18}$

Herein, the reaction was carried out only in the $5^{\text {th }}$ position of the pyrimidine ring, because the ethanolic group which is present in the position 5 is easily removed by boiling in presence of catalyst and hydrazine carbothioamide. ${ }^{19,20}$ The synthesized 10 derivatives of 5-(5-amino-1, 3, 4-thiadiazole-2-yl)-3,4-dihydro-6-methyl-4-phenyl-pyrimidin-2(1H)-one and 10 derivatives of 3,4-dihydro-5-(5-mercapto-4H-1,2,4-triazol-3-yl)-6methyl-4-phenylpyrimidin-2(1H)-one are subjected to

*For correspondence in vitro study of antibacterial activities by using three different species namely, Pseudomonas aeruginosa (Gram-ve), Staphylococcus aureus (Gram +ve) and Escherichia coli (Gram-ve). The inhibition values are compared with standard drug, ciprofloxacin. All the synthesized compounds were characterized by using elemental analysis, mass spectra, ${ }^{1} \mathrm{H}$ and ${ }^{13} \mathrm{C}$ NMR spectra.

\section{Experimental}

Melting points were determined using open capillary method and are uncorrected. The compounds are checked for homogeneity by TLC on silica gel-G using pet ether and ethyl acetate as eluent in 3:5 ratio. The IR spectra were recorded on FT-IR THERMO NICOLET AVATAR 370 spectrometer using $\mathrm{KBr}$ disc. The ${ }^{1} \mathrm{H}$ and ${ }^{13} \mathrm{C}$ NMR were recorded on Bruker Avance-III 400 $\mathrm{MHz}$ - NMR spectrometer using DMSO- $d_{6}$. Elemental analyses were recorded on elemental vario EL III instrument. The mass spectra were recorded on Joel GC-mate spectrometer. All the compounds gave satisfactory micro analytical results.

\subsection{General Procedure}

The synthesize 5-(hydrazine carbothioamide)-3,4-dihydro-6-methyl-4-phenyl pyrimidin-2(1H)-one (Scheme 1) 


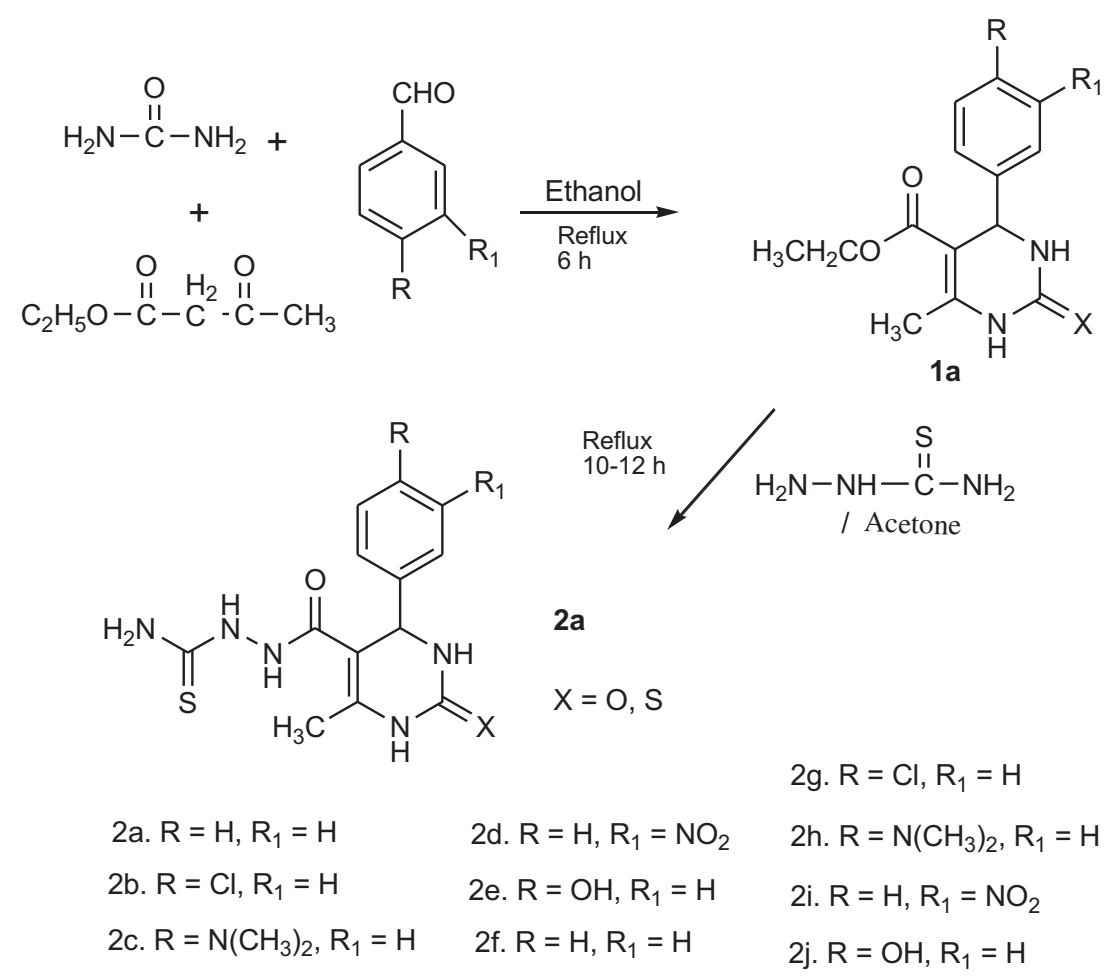

Scheme 1. Synthesis of 5-(hydrazine carbothioamide)-3,4-dihydro-6-methyl-4-phenyl pyrimidin-2 (1H)-one 2(a-j).

2(a-j), an equimolar mixture of compound $\mathbf{1 a}(2.61 \mathrm{~g}$, $0.01 \mathrm{~mol})$ and thiosemicarbazide $(0.91 \mathrm{~g}, 0.01 \mathrm{~mol})$ in acetone was refluxed for $10-12 \mathrm{~h}$ and allowed to cool. The yellow crude solid was purified by recrystallization from alcohol. M.p.: $139-141^{\circ} \mathrm{C}$. [Yield: $2.4 \mathrm{~g}, 82 \%$ ] Analysis: Calculated (\%) for $\mathrm{C}_{13} \mathrm{H}_{15} \mathrm{O}_{2} \mathrm{~N}_{5} \mathrm{~S}$ : C, 51.17; $\mathrm{H}, 4.94 ; \mathrm{N}, 22.50 ; \mathrm{S}, 10.47$. Found (\%): C, 51.10; H, 4.85; N, 22.24; S, 10.94. GCMS: $m / z 305\left[\mathrm{M}^{+}\right]$. FTIR $\left(\mathrm{KBr}, \mathrm{cm}^{-1}\right): 3365,3241,3116(\mathrm{NH}), 3079(\mathrm{Ar}-\mathrm{H})$, $2978(\mathrm{CH}), 1724(\mathrm{C}=\mathrm{O}), 1385(\mathrm{C}-\mathrm{N}), 1219(\mathrm{C}=\mathrm{S})$, $1089(\mathrm{~N}-\mathrm{N}) .{ }^{1} \mathrm{H}$ NMR $\left(400 \mathrm{MHz}, \mathrm{DMSO}-d_{6}\right): \delta 2.251$ $(\mathrm{s}, 3 \mathrm{H}), 5.152(\mathrm{~d}, J=3.2 \mathrm{~Hz}, 1 \mathrm{H}), 6.501(\mathrm{~s}, 2 \mathrm{H}), 7.213-$ $7.336(\mathrm{~m}, 5 \mathrm{H}), 7.702(\mathrm{~d}, J=2.8 \mathrm{~Hz}, 1 \mathrm{H}), 8.175(\mathrm{~d}$, $J=6.4 \mathrm{~Hz}, 2 \mathrm{H}$,), 9.149 (s, 1H). ${ }^{13} \mathrm{C}$ NMR $(400 \mathrm{MHz}$, DMSO- $\left.d_{6}\right): \delta 17.72,59.17,99.33,126.21,127.23$, $128.34,148.25,151.71,152.16,165.33,178.40$.

2.2 General procedure for synthesis of 5-(5-amino-1, 3, 4-thiadiazole-2-yl)-3, 4-dihydro-6-methyl-4-phenylpyrimidin-2(1H)-one (Scheme 2), 3(a-j)

Hydrazine carbothioamide 2a (3.05 g, $0.01 \mathrm{~mol})$ was dissolved in $5 \mathrm{~mL}$ conc. $\mathrm{H}_{2} \mathrm{SO}_{4}$. This solution was stirred at RT and left overnight. It was then poured in crushed ice. The resulting suspension was kept in ammoniacal water for $2 \mathrm{~h}$, filtered and purified by recrystallization from alcohol as white crystals. M.p.: 174-176 ${ }^{\circ}$ C. [Yield: $2.7 \mathrm{~g}$; 81\%]. ${ }^{1} \mathrm{H}$ NMR (400 MHz,
DMSO- $\left.d_{6}\right): \delta 2.258(\mathrm{~s}, 3 \mathrm{H}), 4.004(\mathrm{~s}, 2 \mathrm{H}), 5.159(\mathrm{~d}, J$ $=3.2 \mathrm{~Hz}, 1 \mathrm{H}), 7.227-7.347(\mathrm{~m}, 5 \mathrm{H}), 7.701(\mathrm{~d}, J=2$ $\mathrm{Hz}, 1 \mathrm{H}), 9.151$ (s, 1H). ${ }^{13} \mathrm{C}$ NMR (400 MHz, DMSO$\left.d_{6}\right): \delta 17.03,59.15,99.30,126.20,127.20,128.34$, 144.82, 148.27, 152.10, 165.32. FT-IR $\left(\mathrm{KBr}, \mathrm{cm}^{-1}\right)$ : 3354, 3227, $3110(\mathrm{NH}), 3027(\mathrm{Ar}-\mathrm{H}), 2976(\mathrm{CH}), 1689$ $(\mathrm{C}=\mathrm{O}), 1460(\mathrm{C}=\mathrm{N}), 1225(\mathrm{C}-\mathrm{S}), 1378(\mathrm{C}-\mathrm{N}), 1098$ $(\mathrm{N}-\mathrm{N})$. GCMS: $m / z 287\left[\mathrm{M}^{+}\right]$. Analysis: Calculated (\%) for $\mathrm{C}_{13} \mathrm{H}_{13} \mathrm{ON}_{5} \mathrm{~S}$ : C, 54.38; $\mathrm{H}, 4.56 ; \mathrm{N}, 24.39 ; \mathrm{S}$, 11.13. Found (\%): C, 54.35; H, 4.56; N, 24.64; S, 11.68.

2.3 General procedure for Synthesis of 3,4-dihydro-5(5-mercapto-4H-1,2,4-triazol-3-yl)-6-methyl-4-phenyl pyrimidin-2(1H)-one (Scheme 3) $4(a-j)$

The carbothioamide 2a (3.05 g, $0.01 \mathrm{~mol})$ was added into $(8 \mathrm{~g}$ in $100 \mathrm{~mL}) 8 \% \mathrm{NaOH}$; it was refluxed for $4 \mathrm{~h}$. The reaction mixture was cooled to room temperature and acidified with dilute acetic acid, then filtered and washed well with water and purified by recrystallization from alcohol as shiny crystals. M.p.:119-121 ${ }^{\circ} \mathrm{C}$, [Yield: $2.42 \mathrm{~g} ; 80 \%$ ]. ${ }^{1} \mathrm{H}$ NMR $\left(400 \mathrm{MHz}, \mathrm{DMSO}-d_{6}\right): \delta 2.304$ $(\mathrm{s}, 3 \mathrm{H}), 3.217(\mathrm{~s}, 1 \mathrm{H}), 5.507(\mathrm{~d}, J=3.6 \mathrm{~Hz}, 1 \mathrm{H}), 6.975$ (s, 1H), 7.268-7.338 (m, 5H), $7.766(\mathrm{~d}, J=2.4 \mathrm{~Hz}$, $1 \mathrm{H}), 9.217(\mathrm{~s}, 1 \mathrm{H}) .{ }^{13} \mathrm{C}$ NMR $\left(400 \mathrm{MHz}, \mathrm{DMSO}-d_{6}\right)$ : $\delta 17.74,59.14,99.24,126.22,127.21,128.33,144.84$, 148.29, 152.15, 155.11, 165.32. FT-IR $\left(\mathrm{KBr}, \mathrm{cm}^{-1}\right)$ : $3423(\mathrm{NH}), 3027(\mathrm{Ar}-\mathrm{H}), 2968(\mathrm{CH}), 2235(\mathrm{SH})$, 
<smiles>[R]c1ccc(C2NC([X])NC(C)=C2C(=O)NNC(N)=S)cc1[R]</smiles>

2a

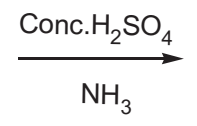

$\mathrm{X}=\mathrm{O}, \mathrm{S}$<smiles>[X]C1=NC(c2ccc([R])c([R])c2)C(c2nnc(N)s2)=C(C)N1</smiles>

3a

$$
\begin{array}{ll}
\text { 3a. } R=H, R_{1}=H & \text { 3d. } R=H, R_{1}=N_{3} \\
\text { 3b. } R=C l, R_{1}=H & \text { 3e. } R=O H, R_{1}=H \\
\text { 3c. } R=N\left(C_{3}\right)_{2}, R_{1}=H & \text { 3f. } R=H, R_{1}=H
\end{array}
$$$$
\text { 3g. } \mathrm{R}=\mathrm{Cl}, \mathrm{R}_{1}=\mathrm{H}
$$$$
\text { 3h. } \mathrm{R}=\mathrm{N}\left(\mathrm{CH}_{3}\right)_{2}, \mathrm{R}_{1}=\mathrm{H}
$$$$
\text { 3i. } \mathrm{R}=\mathrm{H}, \mathrm{R}_{1}=\mathrm{NO}_{3}
$$

Scheme 2. Synthesis of 5-(5-amino-1, 3, 4-thiadiazole-2-yl)-3, 4-dihydro-6-methyl-4-phenyl pyrimidin-2(1H)-one 3(a-j).<smiles>[R]c1ccc(C2NC([X])NC(C)=C2C(=O)NNC(N)=S)cc1[R]</smiles>

2a

$$
\begin{aligned}
& \text { 4a. } R=H, R_{1}=H \\
& \text { 4b. } R=C I, R_{1}=H \\
& \text { 4c. } R=N\left(C H_{3}\right)_{2}, R_{1}=H
\end{aligned}
$$

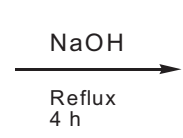

$$
X=O, S
$$$$
\text { 4d. } \mathrm{R}=\mathrm{H}, \mathrm{R}_{1}=\mathrm{NO}_{3}
$$$$
\text { 4e. } \mathrm{R}=\mathrm{OH}, \mathrm{R}_{1}=\mathrm{H}
$$$$
\text { 4f. } R=H, R_{1}=H
$$<smiles>[R]c1ccc(C2NC([X])NC(C)=C2c2nnc(S)[nH]2)cc1[R]</smiles>

$4 a$

Scheme 3. Synthesis of 3,4-dihydro-5-(5-mercapto-4H-1,2,4-triazol-3-yl)6-methyl-4-phenyl pyrimidin-2(1H)-one $\mathbf{4}(\mathbf{a}-\mathbf{j})$.

$1654(\mathrm{C}=\mathrm{O}), 1590(\mathrm{C}=\mathrm{N}), 1373(\mathrm{C}-\mathrm{N}), 1057(\mathrm{~N}-\mathrm{N})$. GCMS: $m / z 287\left[\mathbf{M}^{+}\right]$. Analysis: Calculated $(\%)$ for $\mathrm{C}_{13} \mathrm{H}_{13} \mathrm{ON}_{5} \mathrm{~S}$ : C, 54.38; H, 4.56; N, 24.39; S, 11.13. Found (\%): C, 54.41; H, 4.22; N, 24.35; S, 11.53.

\section{Results and Discussion}

Compounds $\mathbf{3}(\mathbf{a}-\mathbf{j})$ and $\mathbf{4}(\mathbf{a}-\mathbf{j})$ were synthesized as per the Schemes 1, 2 and 3. The final compound 3a was prepared by the reaction of hydrazine carbothioamide 2a, conc. $\mathrm{H}_{2} \mathrm{SO}_{4}$ and $\mathrm{NH}_{3}$, whereas 4a was prepared by refluxing hydrazine carbothioamide $\mathbf{2 a}$ with $\mathrm{NaOH}$. Hydrazine carbothioamide $\mathbf{2 a}$ was synthesized by reaction of pyrimidine ethyl ester $\mathbf{1}$ with thiosemicarbazide in acetone, followed by condensation reaction.

The pyrimidine ethyl ester 1a was prepared by the reaction of benzaldehyde, ethylacetoacetate and urea or thiourea in the presence of mineral acid, followed by Biginelli reaction. The structures of the synthesized compounds were confirmed by IR, ${ }^{1} \mathrm{H}$ and ${ }^{13} \mathrm{C}$ NMR, GC-MS and CHN analysis. Formation of $\mathbf{2 a}$ was confirmed by the presence of $\mathrm{N}-\mathrm{H}$ stretching peaks at 3365 , $3241 \mathrm{~cm}^{-1}$ and $3116 \mathrm{~cm}^{-1}$ and $\mathrm{C}=\mathrm{O}$ stretching peaks at $1724 \mathrm{~cm}^{-1}$ in IR and singlet at $\delta 6.50$ for $\mathrm{NH}_{2}$ group in ${ }^{1} \mathrm{H}$ NMR spectrum.

Treatment of compound 2a with conc. $\mathrm{H}_{2} \mathrm{SO}_{4}$ and $\mathrm{NH}_{3}$, furnished 5-(5-amino-1,3,4-thiadiazol-2-yl)-3,4dihydro-6-methyl-4-phenyl pyrimidin-2(1H)-one (3a). The structure of 3a was elucidated on the basis of $\mathrm{C}-\mathrm{S}$ linkage in the thiadiazole ring, which causes a sharp absorption band at $1225 \mathrm{~cm}^{-1}$ in its IR spectrum. ${ }^{1} \mathrm{H}$ NMR spectrum shows a singlet at $\delta 4.00$ due to $\mathrm{NH}_{2}$ functional group of the compound $\mathbf{3 a}$. The mechanism for compounds $\mathbf{3}(\mathbf{a}-\mathbf{j})$ is shown in Scheme 4. 


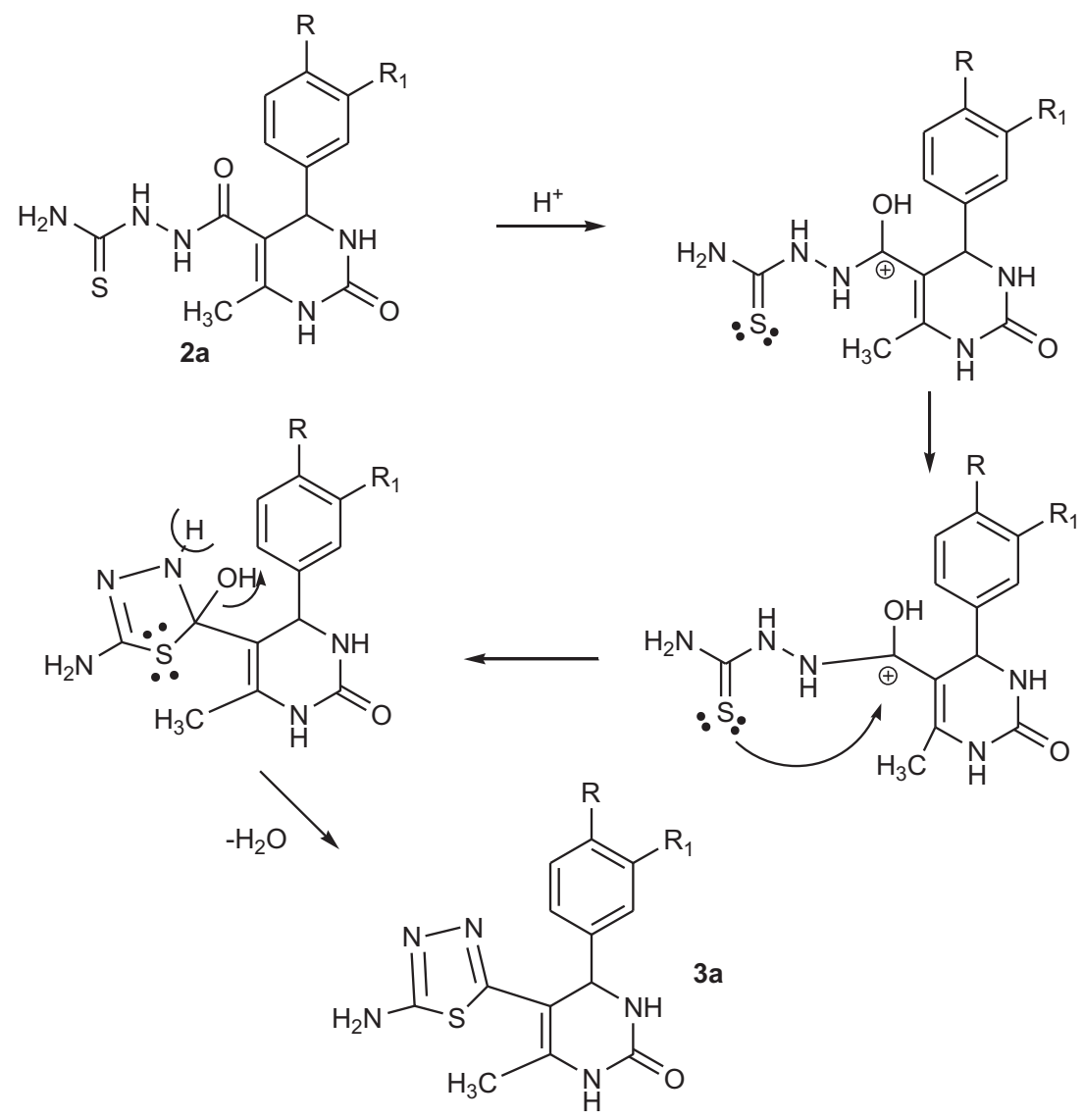

Scheme 4. Mechanism of 5-(5-amino-1, 3, 4-thiadiazole-2-yl)-3, 4-dihydro6-methyl-4-phenyl pyrimidin-2(1 $\boldsymbol{H})$-one $\mathbf{3}(\mathbf{a}-\mathbf{j})$.

The IR and ${ }^{1} \mathrm{H}$ NMR spectral data reveal that the carbonyl absorption band at $1689 \mathrm{~cm}^{-1}$ of $\mathrm{NH}-\mathrm{CO}-$ $\mathrm{NH}$ group, N-N stretching band at $1098 \mathrm{~cm}^{-1}$, aliphatic $\mathrm{C}-\mathrm{H}$ and aromatic C-H stretching at $2976 \mathrm{~cm}^{-1}$ and $3027 \mathrm{~cm}^{-1}$, in the pyrimidine compound 3a. Mass spectrum also supports the proposed structure by the presence of molecular ion peak at $m / z 287 \mathrm{M}^{+}$.

The structure of (4a) was elucidated on the basis of $\mathrm{C}-\mathrm{N}$ linkage in the triazole ring, which causes an absorption band at $1373 \mathrm{~cm}^{-1}$ in its IR spectrum. ${ }^{1} \mathrm{H}$ NMR spectrum shows a singlet at $\delta 3.21$ due to $\mathrm{SH}$ functional group of compound 4a. The IR and ${ }^{1} \mathrm{H}$ NMR spectral data reveal that the carbonyl absorption band at $1654 \mathrm{~cm}^{-1}$ of NH-CO-NH group, $\mathrm{N}-\mathrm{N}$ stretching band at $1053 \mathrm{~cm}^{-1}$, aliphatic $\mathrm{C}-\mathrm{H}$ and aromatic $\mathrm{C}-\mathrm{H}$ stretching at $2968 \mathrm{~cm}^{-1}$ and $3027 \mathrm{~cm}^{-1}$, in the group of pyrimidine compound (4a). Molecular ion peak at $\mathrm{m} / \mathrm{z}$ $287 \mathrm{M}^{+}$in the mass spectrum also supports the proposed structure. The mechanism of compounds $4(\mathbf{a}-\mathbf{j})$ is shown in Scheme 5.

All these compounds were screened for antibacterial activity by pseudomonas aeruginosa (Gram-ve), staphylococcus aureus (Gram +ve) and escherichia coli (Gram-ve). Ciprofloxacin was used as standard drug. Most of the synthesized compounds showed moderate to good inhibition at a concentration of $10 \mu \mathrm{g} / \mathrm{mL}$.

\subsection{Antibacterial studies}

The newly synthesized pyrimidine derivatives were screened for their antibacterial activity in vitro against pseudomonas aeruginosa, staphylococcus aureus and escherichia coli, using agar well disk diffusion method. The test compounds were dissolved in DMSO to get a solution of $10 \mu \mathrm{g} / \mathrm{mL}$ concentration. The inhibition zones were measured in millimeters at the end of an incubation period of $18 \mathrm{~h}$ at $37^{\circ} \mathrm{C}$. Ciprofloxacin was used as a standard drug and the results are shown in Tables 1 and 2. The investigation of antibacterial screening data reveals that, all the tested compounds show moderate to good inhibition at $10 \mu \mathrm{g} / \mathrm{mL}$ concentration.

\subsection{Comparison of anti bacterial activity}

Comparison of antibacterial activity for all the synthesised compounds are shown in Figures S1-S3 (in Supplementray Information). Based on the comparative 
<smiles>[R]c1ccc(C2NC(=O)NC(C)=C2C(=O)NNC(=S)N(C)C(C)O)cc1[R]</smiles><smiles>[R]c1ccc(C2NC(=O)NC(C)=C2C(=O)NNC(N)=S)cc1[R]</smiles><smiles>[R]c1ccc(C2NC(=O)NC(C)=C2C(=O)NCCC)cc1[R]</smiles><smiles>[R]c1ccc(C2NC(=O)NC(C)=C2C(=O)NN(C)NC(=S)NCCCC)cc1[R]</smiles><smiles>[R]c1ccc(C2NC(=O)NC(C)=C2C(=O)N=NC(=N)S)cc1[R]</smiles><smiles>[R]c1ccc(C2NC(=O)NC(C)=C2C2COCC23CN=NC3S)cc1[R]</smiles><smiles>[R]c1ccc(C2NC(=O)NC(C)=C2c2nnc(S)[nH]2)cc1[R]</smiles>

Scheme 5. Mechanism of 3,4-dihydro-5-(5-mercapto-4H-1,2,4-triazol-3yl)-6-methyl-4-phenyl pyrimidin-2(1H)-one 4(a-j).

Table 1. Antibacterial activity of compounds $\mathbf{3}(\mathbf{a}-\mathbf{j})$.

\begin{tabular}{lccc}
\hline Compound & $\begin{array}{c}\text { Pseudomonas } \\
\text { aeruginosa }(\mathrm{mm})\end{array}$ & $\begin{array}{c}\text { Staphylococcus } \\
\text { aureus }(\mathrm{mm})\end{array}$ & $\begin{array}{c}\text { Escherichia coli } \\
(\mathrm{mm})\end{array}$ \\
\hline Control (DMSO) & 0 & 0 & 0 \\
3a & 6 & 7 & 7 \\
3b & 5 & 7 & 8 \\
3c & 5 & 8 & 9 \\
3d & 5 & 5 & 8 \\
3e & 14 & 16 & 18 \\
3f & 5 & 5 & 6 \\
3g & 7 & 10 & 6 \\
3h & 5 & 5 & 10 \\
3i & 5 & 8 & 14 \\
3j & 10 & 11 & \\
\hline
\end{tabular}


Table 2. Antibacterial activity of compounds $4(\mathbf{a}-\mathbf{j})$.

\begin{tabular}{lccc}
\hline Compound & $\begin{array}{c}\text { Pseudomonas } \\
\text { aeruginosa }(\mathrm{mm})\end{array}$ & $\begin{array}{c}\text { Staphylococcus } \\
\text { aureus }(\mathrm{mm})\end{array}$ & $\begin{array}{c}\text { Escherichia coli } \\
(\mathrm{mm})\end{array}$ \\
\hline Control (DMSO) & 0 & 0 & 0 \\
$\mathbf{4 a}$ & 7 & 8 & 8 \\
$\mathbf{4 b}$ & 9 & 12 & 11 \\
$\mathbf{4 c}$ & 5 & 7 & 7 \\
$\mathbf{4 d}$ & 5 & 7 & 5 \\
$\mathbf{4 e}$ & 20 & 14 & 10 \\
$\mathbf{4 f}$ & 7 & 8 & 14 \\
$\mathbf{4 g}$ & 23 & 6 & 15 \\
$\mathbf{4 h}$ & 8 & 10 & 12 \\
$\mathbf{4 i}$ & 10 & 10 & 9 \\
$\mathbf{4 j}$ & 8 & & \\
\hline
\end{tabular}

studies, 5-(5-amino-1,3,4-thiadiazol-2-yl)-3,4-dihydro-6methyl-4-phenylpyrimidin-2(1H)-one, $\mathbf{3}(\mathbf{a}-\mathbf{j})$ compounds have less inhibition than the 3,4-dihydro-5-(5-mercapto4H-1,2,4-triazol-3-yl)-6-methyl-4-phenylpyrimidin-2(1H)one $\mathbf{4}(\mathbf{a}-\mathbf{j})$ compounds at $10 \mu \mathrm{g} / \mathrm{mL}$ concentration. A few compounds showed very good inhibition, which are closer to the standard drug.

\section{Conclusions}

The investigation of antibacterial screening data for synthesized compounds reveal that, the $\mathbf{4}(\mathbf{a}-\mathbf{j})$ triazole substituted compounds have higher inhibition than the $\mathbf{3}(\mathbf{a}-\mathbf{j})$ thiadiazole substituted compounds, because the triazole ring which is substituted in the pyrimidine, enhances the inhibition of the compound, against the three species of pseudomonas aeruginosa, staphylococcus aureus and escherichia coli.

\section{Supplementary Information (SI)}

All additional information pertaining to characterization of the compounds using FT-IR spectra (Figures S1 to S10 and $\mathrm{S} 31$ to S40), ${ }^{1} \mathrm{H}$ NMR spectra (Figures S11 to S20 and S41 to S50), ${ }^{13}$ C NMR spectra (Figures S21 to S30 and S51 to S60), antibacterial screening data (Tables S1, S2) and antibacterial activities comparative diagram (Figure S1, S2 and S3) are given in the supporting information available at www.ias.ac. in/chemsci.

\section{Acknowledgements}

The authors are thankful to the Principal and Research Department of Chemistry, Islamiah College, Vaniyambadi, Vellore district, Tamil Nadu, India for constant encouragement and providing necessary facilities.

\section{References}

1. Mohd A, Kumar A, Ali I and Khan S A 2009 The synthesis of pharmaceutically important 1,3,4-thiadiazole and imidazolinone derivatives: Antimicrobial studies of heterocyclic compounds Indian J. Chem. 481288

2. Xiang Li, He-Mei Liu, Xui-Zhang and Zhi-Hui 2012 Synthesis and evaluation of antitumor activities of Novel chiral 1,2,4-triazole derivatives: A study of Schiff bases bearing $\gamma$-butenolide moiety Org. Med.Chem. Lett. 21

3. Karaarslan M, Kopair P, Cansiz A, Orek C and Sap O 2012 Synthesis and antimicrobial activity of some new 5-(Pyridin-4-yl)-3-thioacetamido-1,2,4-triazole derivatives: Antimicrobial studies of substituted triazole Chem. Sci. Trans. 1226

4. Merchant J R, Suneel Y and Dike 1978 Synthesis of some 2,4-diamino-pyrrolo-pyrimidines: A study of substituted pyrimidine J. Chem. Sci. 87229

5. EI-Sayed R 2006 Synthesis, antibacterial and surface activity of 1,2,4-triazole derivatives: Antibacterial studies of triazole Indian J. Chem. $\mathbf{4 5} 738$

6. Andrews B and Ahmed M 2013 Novel synthesis and characterization of some pyrimidine derivatives of oxadiazoles, triazoles and thiadiazoles: Synthesis of substituted pyrimidine derivatives Asian J. Chem. 252070

7. Andrews B and Ahmed M 2015 An efficient synthesis, characterization and anti-bacterial activity of pyrimidine bearing 1,3,4-thiadiazole derivatives: A study of pyrimidine moiety Indian J. Chem. $\mathbf{5 4} 406$

8. Ilangovan A, Saravanakumar S and Umesh S 2015 T3P as an efficient cyclodehydration reagent for the onepot synthesis of 2-amino-1,3,4-oxadiazoles: A study of substituted oxadiazole J. Chem. Sci. 127797

9. Kushal R, Lanjewar Mukund S and Binda D 2009 Synthesis and antimicrobial activity of 5-(2-aminothiazol-4-yl)-3,4-dihydro-4-phenyl pyrimidin-2(1H)-one: Synthesis of pyrimidine compound Indian J. Chem. 48 1732

10. Kape C O 2000 Dihydropyrimidine synthesis Eur. J. Med. Chem. 351043

11. Kape C O 1993 Biginelli dihydropyrimidine synthesis Tetrahedron 496937

12. Nagarajan S, Tanveer M, Shaikh and Kandasamy E 2015 Synthesis of 1-alkyl triazolium triflate room temperature 
ionic liquids and their catalytic action: Studies in multi-component Biginelli reaction J. Chem. Sci. 127 1539

13. Manjula A, Rao B V and Neelakantam P 2004 An inexpensive protocol for Biginelli reaction: Synthesis of pyrimidine compound Synth. Commun. 34 2665

14. Andrew J, Zych Hong-Jun Wang, Samuel A and Sakwa 2010 Synthesis and Suzuki-Miyaura reaction: Synthesis of dihydropyrimidine-2(1H)-one Tetrahedron Lett. 51 5103

15. Garima, Srivastava V P and Yadav L D S 2010 Biginelli reaction: Starting directly from alcohol Tetrahedron Lett. $\mathbf{5 1} 6436$

16. Reddy Y T, Reddy P N, Kumar B S and Rajitha B 2005 Bismuth oxide perchlorate catalysed: Synthesis of dihydropyrimidine-2 compound Indian J. Chem. 44B 1304
17. Bose D S, Fathima L and Mereyala H B 2003 Synthesis of 5-alleoxycarbonyl-4-aryl-3,4-dihydropyrimidine2(1H)-one: Synthesis of multi-compounds J. Org. Chem. 68587

18. Sergey V, Ryabukhin Andrey S, Plaskon Semen S, Bondarenko Eugeniy N, Ostapchuk Oleksandr O, Grygorenko Oleg V and Tolmachev 2010 Acyl pyruvates as synthos: Biginelli reaction Tetrahedron Lett. 514229

19. Rosenani A, Haque and Salam M A 2015 Synthesis, structural characterization and biological activities of organotin(IV) complexes with methoxybenzaldehyde: Synthesis of thiosemicarbazone J. Chem. Sci. 1271589

20. Ramchander J, Rameshwar N, Reddy T S, Raju G and Reddy A R 2014 Synthesis and photophysical properties of 1,4-disubstituted naphthloxymethyl-N-alkyl naphthimide-1,2,3-triazole: Synthesis of substituted triazole J. Chem. Sci. 1261063 